\title{
Reformasi Sistem Pensiun Pasca Undang-Undang Nomor 5 Tahun 2014 Tentang Aparatur Sipil Negara Guna Mewujudkan Kesejahteraan Bagi Pegawai Negeri Sipil
}

\author{
Fiqi Fatichadiasty \\ Program Magister Ilmu Hukum Universitas Indonesia, Jakarta, Indonesia \\ E-mail: zoelkifliismail@gmail.com
}

\begin{tabular}{l}
\hline Info Artikel \\
\hline \\
Keywords: \\
Pension Reform; \\
Well-being; State \\
Civil Apparatus. \\
\\
Kata Kunci: \\
Keformasi Pensiun; \\
Aparatur Sipil \\
Negara. \\
\hline
\end{tabular}

\begin{tabular}{l} 
Abstract \\
Pension is a right that is obtained by a civil servant. Civil servants \\
with the aim of improving welfare. This is in accordance with Law \\
Number 43 of 1999 concerning Personnel Fundamentals, Article 32 \\
which states to increase the excitement that is carried out by seeking \\
the welfare efforts of Civil Servants, welfare businesses that contain \\
remuneration programs. However, there are still some shortcomings \\
in one of the retirement age limits that have not been clearly \\
stipulated in a regulation. With this research, it is expected to discuss \\
a complete and in-depth acceptance of the substantive revenue from \\
the Civil Servants Retirement Age Limit and also changes in the \\
income system stated by the government. The methodology used in \\
this study consists of a qualitative description and study of the \\
process of reforming the civil service recipient system, which is \\
distributed in terms of legal basis. After the enactment of Law \\
Number 5 of 2014 concerning State Civil Apparatus. \\
Abstrak \\
Pensiun adalah hak yang diperoleh oleh pegawai negeri sipil. \\
Pegawai negeri sipil dengan tujuan meningkatkan kesejahteraan. Hal \\
ini sesuai dengan Undang-Undang Nomor 43 Tahun 1999 tentang \\
Pokok-Pokok Kepegawaian, Pasal 32 yang menyatakan untuk \\
meningkatkan kegembiraan yang dilakukan dengan mengupayakan \\
upaya kesejahteraan PNS, usaha kesejahteraan yang memuat \\
program pengupahan. Namun, masih ada beberapa kekurangan \\
dalam salah satu batasan Batas Usia Pensiun (BUP) yang belum \\
diatur secara jelas dalam satu peraturan. Dengan penelitian ini, \\
diharapkan dapat membahas penerimaan yang lengkap dan \\
mendalam tentang penerimaan substantif dari Batas Usia Pensiun \\
PNS dan juga perubahan dalam sistem pendapatan yang dinyatakan \\
oleh pemerintah. Metodologi yang digunakan dalam penelitian ini \\
terdiri dari deskripsi kualitatif dan studi tentang proses reformasi \\
sistem penerima PNS, yang didistribusikan dalam hal dasar \\
hukumnya. Setelah diberlakukannya Undang-Undang Nomor 5 \\
Tahun 2014 tentang Aparatur Sipil Negara (ASN). \\
\hline
\end{tabular}




\section{A. PENDAHULUAN}

Pensiun merupakan dambaan memperoleh penghasilan setelah masa kerja. Setelah usia pensiun tentunya pegawai negeri memasuki masa yang kurang produktif sehingga jaminan masa depan sangat diperlukan. Dengan adanya program dana pensiun maka pegawai negeri yang akan memasuki usia pensiun tidak perlu khawatir. Selain itu dana tersebut bisa digunakan sebagai modal usaha setelah ia pensiun. Pensiun merupakan jaminan hari tua dan sebagai penghargaan atas jasa-jasa pegawai negeri selama bertahuntahun bekerja dalam Dinas Pemerintah. Dengan demikian dapatdikatakan bahwa sifat pensiun pegawai negeri sipil adalah sebagai "jaminan hari tua" dan sebagai "penghargaan".

Di negara-negara maju, penyelenggaraan program pensiun sebagai salah satu bentuk kesejahteraan bagi pegawai, baik pemerintah maupun perusahaan-perusahaan swasta telahdilakukan sejak tahun 1800-an.Ide dana pensiun diselenggarakan untuk memberikan jaminan kesejahteraan bagi pegawai dan keluarganya pada saat pegawai memasuki masa pensiun atau mengalami kecelakaan semasa kerja yang mengakibatkan cacat tubuh atau meninggal dunia. Jaminan kesejahteraan tersebut dalam bentuk pensiun (pension benefit) diberikan kepada pegawai dan keluarganya yang dibayarkan secara berkalasesuai dengan peraturan dana pensiun. Di Negara-negara maju penyelenggaraan program pensiun sudah dilakukan sejak tahun 1800-an. Di Canada Undang-Undang Dana Pensiun yang dikenal dengan nama Pension Fund Societies Act of 1887, mulai dilaksanakan sejak tahun 1887, merupakan program pensiun untuk pegawai pemerintah federal, karyawan kereta api, dan lembaga-lembaga keuangan lainnya. ${ }^{1}$

Mengingat pentingnya peranan Pegawai Negeri Sipil (PNS) dalam pembangunan nasional maka perlu diberikan perlindungan, pemeliharaan, serta peningkatan kesejahteraan sehingga pada gilirannya akan dapat meningkatkan produktivitas kerja. ${ }^{2}$ Usaha peningkatan kesejahteraan Pegawai Negeri Sipil (PNS) dan keluarganya dilakukan melalui penyelenggaraan program pensiun PNS. Berdasarkan keputusan menteri pertama RI No: 388/MP1960 disebutkan bahwa " perlunya pembentukan jaminan sosial bagi Pegawai Negeri Sipil dan keluarganya pada saat mengakhiri pengabdiannya kepada negara". Program tersebut ditujukan untuk kesejahteraan Pegawai Negeri Sipil (PNS), yakni memberikan jaminan keuangan bagi peserta bila mendapat resiko yang mengakibatkan peserta tersebut tidak mampu lagi bekerja karena sudah tua atau mencapai usia tidak produktif lagi untuk melaksanakan tugas-tugas pemerintahan yang diembankan kepada peserta atau jaminan keuangan bagi ahli warisnya apabila peserta tertimpa resiko kematian sebelum mencapai usia pensiun atau tertimpa resiko kematian ketika menjalani masa pensiun.

Sebagai bagian akhir dari siklus manajemen Pegawai Negeri Sipil (PNS), pemberhentian dan pensiun mendapatkan perhatian serius dari pemerintah. Bukti keseriusan itu adalah diaturnya pensiun PNS dalam suatu kebijakan berupa undangundang (UU), yaitu UU Nomor 11 Tahun 1969 tentang Pensiun Pegawai dan Pensiun Janda/Duda Pegawai. Dalam hierarki peraturan perundang-undangan, hal itu sejajar dengan UU Nomor 43 Tahun 1999 tentang Perubahan atas UU Nomor 8 Tahun 1974 tentang Pokok-Pokok Kepegawaian yang mengatur manajemen PNS. Selain menyiratkan keseriusan, hal tersebut juga dapat menjadi indikasi bahwa pemberhentian dan pensiun pegawai adalah sesuatu yang tidak kalah penting dibandingkan dengan unsur manajemen

1 Deasy Ayu, "Dana Pensiun Pegawai Negeri Sipil”, Https://Www.Academia.Edu/30712453/DANA _PENSIUN_PEGAWAI_NEGERI_SIPIL, (Diakses pada 22 November 2019).

2 http://Taspen.Co.Id, (Diakses pada 22 November 2019). 
PNS yang lain, seperti perencanaan, pengorganisasian, pelaksanaan, pengembangan, dan pengawasan. $^{3}$

Desakan untuk mereformasi sistem pensiun PNS dan jaminan sosial lainnya terjadi di banyak negara. Pencetusnya adalah beban anggaran, isu demografi dan dinamika sosial, ekonomi dan politik. Jika di Eropa terjadi perubahan sistem pensiun PNS dan sistem jaminan sosial secara massif, maka di Indonesia desakan untuk mereformasi sistem pensiun PNS terjadi karena sistem pensiun PNS yang ada sekarang sudah tidak relevan kondisi saat ini baik dari aspek kebijakan, aspek anggaran, aspek kelembagaan, sifat pensiun, manfaat pensiun, kepesertaan, batas usia pensiun maupun prosedur pengajuan pensiun. ${ }^{4}$

Reformasi birokrasi sudah dicanangkan sejak era reformasi, dengan semangat reformasi, undang-undang kepegawaian No. 43 Tahun 1999 mencoba mengakomodasikan kepentingan tersebut. Dalam implementasinya, reformasi birokrasi mengalami bias, banyak yang beranggapan reformasi hanya sebatas perubahan dan adanya remunerasi namun sama sekali belum merubah mind set dan culture set. Kinerja birokrasi masih kedodoran dan belum memuaskan. Dari data tentang penilaian kinerja birokrasi di negara-negara ASEAN. Indonesia hanya diatas Vietnam, namun jauh di bawah Singapura, Malaysia dan Philipina. Indeks efisiensi birokrasi Indonesia adalah 8,37 dari skala 1-10, dimana angka 10 menunjukkan sangat tidak efisien. Lebih dari 4,5 juta PNS yang tersebar di seluruh Indonesia tentu membutuhkan keselarasan, kesamaan gerak dan langkah dalam membangun bangsa. ${ }^{5}$

Menyadari hal ini, pemerintah terus melakukan upaya untuk perbaikan melalui berbagai hal, baik dalam bidang kelembagaan dengan melakukan reformasi kelembagaan, pendidikan dan pelatihan, peningkatan kesejahteraan hingga menetapkan regulasi yang mengatur manajemen kepegawaian secara keseluruhan mulai dari rekrutmen, pendidikan dan pelatihan, pembinaan dan jenjang karir hingga kesejahteraan dan masa pensiun. Sebagai respon atas kritik tentang kinerja dan kondisi birokrasi atau aparatur negara dan menjawab tantangan bangsa ke depan di era global, maka pemerintah bersama DPR RI mengesahkan Undang - Undang No. 5 Tahun 2014 tentang Aparatur Sipil Negara (UU ASN). ${ }^{6}$ Pada 15 Januari 2014 telah disahkan Undang-Undang Nomor 5 Tahun 2014 tentang Aparatur Sipil Negara (ASN). UU itu antara lain mengatur Batas Usia Pensiun (BUP) Pegawai Negeri Sipil (PNS) yang mana dalam UU Pokok Kepegawaian tidak diatur secara rinci, kemudian terdapat perubahan sistem pembiayaan jaminan pension, yang semula menggunakan sistem sehingga penting kiranya untuk mengetahui bagaimanakah pengaturan pensiun bagi Pegawai Negeri Sipil (PNS) dalam UndangUndang Nomor 43 Tahun 1999 Tentang Pokok-Pokok Kepegawaian serta UndangUndang Nomor 5 Tahun 2014 tentang Aparatur Sipil Negara. Sehingga diharapkan kita dapat mengetahui bagaimanakah perbandingan pengaturan pensiun bagi PNS dalam Undang-Undang Nomor 43 Tahun 1999 Tentang Pokok-Pokok Kepegawaian dengan ASN dalam Undang Nomor 5 Tahun 2014 tentang Aparatur Sipil Negara.

${ }^{3}$ Adhi, A. E, "Modul Pengertian Dan Ruang Lingkup Pemberhentian Dan Pensiun Pegawai", Http://Repository.Ut.Ac.Id/3945/1/ADPG4447-M1.Pdf, (Diakses pada 22 November 2019).

4 Dewan Perwakilan Rakyat, "Ringkasan Eksekutif Telaahan Kebijakan Sistem Pensiun PNS“, Http:/Ppid.Lan.Go.Id/Wp-Content/Uploads/2014/10/Telaahan-Kebijakan-Sistem-Pensiun-PNS.Pdf, (Diakses pada 22 November 2019).

5 Badan Perencanaan Pembangunan Nasional, "Menuju Perencanaan Profesional, SIMPUL, Perencanaan", Http://Pusbindiklatren.Bappenas.Go.Id/File/Bukuterbit/Simpul-22.Pdf, (Diakses pada 22 November 2019).

${ }^{6}$ Ibid. 


\section{B. METODE PENELITIAN}

Penulis menggunakan metode penelitian yuridis-normatif. Metode ini merupakan suatu prosedur penelitian ilmiah untuk menemukan kebenaran berdasarkan logika keilmuan hukum dari segi normatifnya. ${ }^{7}$ Selain itu, pendekatan normatif ini dapat dipahami sebagai suatu penelitian asas hukum yang bertitik tolak pada tata hukum tertentu. Dengan metode tersebut maka data-data yang dikumpulkan dalam penelitian ini adalah data sekunder belaka. Data sekunder yang dimaksud adalah data yang tidak diperoleh langusng dari masyarakat, melainkan data yang diperoleh cukup dari bahanbahan kepustakaan. ${ }^{8}$ Data sekunder yang di maksud adalah: Bahan hukum primer, yaitu bahan hukum yang berasal dari hukum yang mengikat. Dalam hal ini adalah Peraturan Perundang-undangan yang di dalam masyarakat diakui sebagai sumber hukum positif di Indonesia. Dalam penelitian kali ini, bahan hukum primer yang akan digunakan oleh penulis adalah Undang-Undang Nomor 43 Tahun 1999 Tentang Pokok-Pokok Kepegawaian dan Undang Nomor 5 Tahun 2014 tentang Aparatur Sipil Negara. Bahan hukum sekunder, yaitu merupakan penjelasan lebih lanjut dari bahan-bahan hukum primer. Termasuk ke dalam bahan hukum sekunder yaitu buku-buku, jurnal-jurnal hukum, makalah-makalah, dan juga artikel-artikel pendukung yang secara umum membahas mengenai hukum administrasi negara, secara khusus membahas peraturan perundangundangan terkait kepegawaian serta topik lainnya yang mendukung pembahasan dari penelitian ini. Bahan hukum tersier, yaitu bahan yang menjadi penunjang dari bahan hukum primer dan bahan hukum sekunder. Di mana di dalamnya mencakup Kamus Besar Bahasa Indonesia dan halaman-halaman Internet. Kedua bahan tersebut digunakan sebagai referensi untuk mencari peristilahan hukum yang berkaitan dengan pembuatan penelitian ini.

\section{PEMBAHASAN}

\section{Pengaturan Pensiun Bagi Pegawai Negeri Sipil (PNS) Dalam Undang-Undang Nomor 43 Tahun 1999 Tentang Pokok-Pokok Kepegawaian}

Hak seorang pegawai negeri sipil diantaranya adalah hak atas pensiun sesuai dengan Pasal 10 Undang-Undang No.8 Tahun 1974 jo Undang-Undang Nomor 43 Tahun 1999tentang Pokok-Pokok Kepegawaian "Setiap Pegawai Negeri Sipil yang telah memenuhi syarat-syarat yang diberikan berhak atas pensiun."Berdasarkan Undangundang No.43 Tahun 1999 Pasal 10, Pensiun adalah jaminan hari tua dan sebagai balas jasa terhadap Pegawai Negeri yang telah bertahun-tahun mengabdikan dirinya kepada Negara. Pada pokoknya adalah menjadi kewajiban setiap orang untuk berusaha menjamin hari tuanya, dan untuk ini setiap Pegawai Negeri Sipil wajib menjadi peserta dari suatu badan asuransi sosial yang dibentuk oleh pemerintah. Karena pensiun bukan saja sebagai jaminan hari tua, tetapi juga adalah sebagai balas jasa, maka Pemerintah memberikan sumbangannya kepada Pegawai Negeri. ${ }^{9}$ Dapat disimpulkan bahwa Pensiun adalah suatukondisi dimana seseorang tidak bekerja lagi sebagai pegawai negeri dengan mendapatkan penghasilan yang teratur.

\footnotetext{
${ }^{7}$ Ibrahim, J. (2005). Teori Dan Metodologi Penelitian Hukum Normatif, Surabaya: Bayu Media Publishing, h. 57.

${ }^{8}$ Ibid., h. 12

9 'Pensiun”, Http://Bkpsdm.Kuningankab.Go.Id/Pelayanan/Pensiun. (Diakses pada 23 November 2019).
}

165 |S A S I Vol. 26 No.2, April - Juni 2020 
Sebelum membahas mengenai pensiun yang lebih mendalam, terlebih dahulu kita harus mengerti apa yang dimaksud dengan Pegawai Negeri tersebut sebagaimana yang diatur dalam Pasal 1 ayat (1) Undang-Undang No.43 Tahun 1999 tentang Perubahan atas UU No.8 Tahun 1974 ialah setiap warga Negara Republik Indonesia yang telah memenuhi syarat yang ditentukan, diangkat oleh pejabat yang berwenang dan diserahi tugas dalam suatu jabatan negeri, atau diserahi tugas negara lainnya, dan digaji berdasarkan Peraturan Perundang-undangan yang berlaku. Sedangkan pejabat yang berwenang adalah pejabat yang mempunyai kewenangan mengangkat, memindahkan, dan memberhentikan Pegawai Negeri berdasarkan peraturan perundang-undangan yang berlaku (Butir 2 Pasal 1 UU Nomor 43 Tahun 1999). Selanjutnya, mengenai Pasal 2 ayat (1) dan (2) disebutkan bahwasanya :

1) Pegawai Negeri terdiri dari :

a) Pegawai Negeri Sipil (PNS);

b) Anggota Tentara Nasional Indonesia; dan

c) Anggota Kepolisian Negara Republik Indonesia.

2) Pegawai Negeri Sipil sebagaimana dimaksud diatas, terdiri dari :

a) Pegawai Negeri Sipil Pusat; dan

b) Pegawai Negeri Sipil Daerah

3) Di samping Pegawai Negeri sebagaimana dimaksud diatas, pejabat yang berwenang dapat mengangkat pegawai tidak tetap.

Dengan demikian, yang dimaksud dengan Pegawai Negeri Sipil adalah unsur Aparatur Negara, Abdi Negara, dan Abdi Masyarakat sebagaimana yang dimaksud dalam Undang-Undang Nomor 43 Tahun 1999 tentang perubahan atas Undang-Undang Nomor 8 Tahun 1974 tentang Pokok-Pokok Kepegawaian. Sebagaimana pengertian akan pensiun sendiri dijelaskan dalam buku Sastra Djatmika dan Marsono bahwa Pensiun adalah suatu penghasilan yang diterima setiap bulan oleh seorang bekas pegawai yang tidak dapat bekerja lagi, untuk membiayai penghidupan selanjutnya, agar tidak terlantar apabila tidak berdaya lagi untuk mencari penghasilan lain. ${ }^{10}$ Lebih jelasnya seorang PNS bisa mendapatkan dana pensiun sebagaimana diatur dalam Pasal 23 ayat (1) UndangUndang Nomor 43 Tahun 1999 yang menyebutkan bahwa PNS diberhentikan dengan hormat karena meninggal dunia. Pada bab penjelasan disebutkan bahwasanya PNS yang diberhentikan dengan hormat menerima hak-hak kepegawaian sesuai dengan peraturan perundang-undangan yang berlaku antara lain hak pensiun dan tabungan hari tua. Lebih lanjut kebijakan setingkat UU yang mengatur pensiun PNS sudah diatur dalam UU Nomor 11 Tahun 1969, tentang Pensiun Pegawai dan Pensiun Janda/Duda.Berikutnya, Pasal 23 ayat (2) menyebutkan PNS juga dapat diberhentikan dengan hormat karena salah satu diantaranya adalah mencapai batas usia pensiun. Namun, dalam undang-undang tersebut tidak pula dijelaskan secara rinci berapa batas usia pegawai negeri sipil yang tergolong dalam masa pensiun.

Batas Usia Pensiun (BUP) Pegawai Negeri Sipil (PNS) pada dasarnya telah diatur dalam Peraturan Pemerintah (PP) Nomor 32 Tahun 1979 tentang Pemberhentian PNS, yaitu 56 (lima puluh enam) tahun. Dan PP Nomor 32 Tahun 1979 ini telah dua kali mengalami perubahan yaitudengan PP Nomor 1 Tahun 1994 dan PP Nomor 65 Tahun 2008. Perpanjangan usia pensiunan sendiri terbagi menjadi tiga bagian yakni: ${ }^{11}$

10 Djatmika, S. dan Marsono. (1995) Hukum Kepegawaian Di Indonesia, Jakarta:Djambatan, h. 253.

11 "Pedoman Pemberhentian PNS", Http://Www.Bkn.Go.Id/In/Peraturan/Pedoman/PedomanBerhenti-Pns.html, (Diakses pada 23 November 2019). 
1) Perpanjangan batas usia pensiun sampai 65 tahun untuk PNS yang memangku jabatan peneliti madya dan peneliti utama dengan tugasnya secara penuh di bidang penelitian atau jabatan lain yang ditentukan oleh Presiden. Kemudian perpanjangan batas usia pensiun bagi PNS yang memangku jabatan struktural Eselon I tertentu pada saat sampai dengan 62 (enam puluh dua) tahun, memperhatikan dengan tegas persyaratan sebagai berikut:

a) Memiliki keahlian dan pengalaman yang sangat dibutuhkan organisasi;

b) Memiliki kinerja yang baik;

c) Memiliki moral dan integritas yang baik dan;

d) Sehat jasmanl dan rohani yang dibuktikan oleh keterangan dokter.

e) Ditetapkan dengan Keputusan Presiden atas usul Pimpinan Instansi/lembaga setelah mendapat pertimbangan dari Tim Penilai Akhir Pengangkatan, Pemindahan dan Pemberhentian Jabatan Struktural Eselon 1.

2) Usia pensiun sampai 60 tahun untuk PNS yang memangku golongan struktural eselon I dan II serta jabatan dokter yang ditugaskan secara penuh pada unit pelayanan kesehatan negeri dan jabatan pengawas sekolah menengah atas atau jabatan lain yang ditentukan oleh Presiden.

3) Usia pensiun 58 tahun untuk PNS yang menjadi hakim pada Mahkamah Pelayaran dan jabatan lain yang ditentukan Presiden.

Sesuai dengan PP Nomor 32 Tahun 1979, BUP dapat diperpanjang bagi PNS yang memangku jabatan tertentu. Jabatan-jabatan tertentu yang diduduki PNS yang dapat diperpanjang BUP-nya ada yang diatur dalam PP Nomor 32 Tahun 1979 dan ada diatur dalam Keputusan Presiden/Peraturan Presiden.Perpanjangan BUP bagi PNS yang telah diatur dalam PP Nomor 32 Tahun 1979, antara lain : ${ }^{12}$

1) 65 (enam puluh lima) tahun bagi PNS yang memangku jabatan Ahli Peneliti dan Peneliti;

2) 60 (enam puluh) tahun bagi PNS yang memangku jabatan : Pimpinan Lembaga Pemerintah Non Departemen, Pejabat Struktural Eselon I, Pejabat Struktural Eselon II, Dokter yang ditugaskan secara penuh pada Lembaga Kedokteran Negeri sesuai profesinya.

Perpanjangan BUP bagi PNS yang telah diatur dalam Keputusan Presiden/Peraturan Presiden, antara lain: ${ }^{13}$

1) 65 (enam puluh lima) tahun bagi PNS yang menduduki jabatan:

a. Dosen, sedangkan bagi Profesor yang berprestasi dapat diperpanjang sampai dengan 70 (tujuh puluh) tahun (UU Nomor 14 Tahun 2005);

b. Ketua, Wakil Ketua, dan Hakim Tingkat Banding di lingkungan Peradilan Umum,PTUN, dan Agama (UU Nomor 8 Tahun 2004, UU Nomor 9 Tahun 2004, dan UU Nomor 3 Tahun 2006).

2) 62 (enam puluh dua) tahun bagi PNS yang menduduki jabatan:

a. Ketua, Wakil Ketua, dan Hakim Tingkat Pertama di lingkungan Peradilan Umum,PTUN, dan Agama (UU Nomor 8 Tahun 2004, UU Nomor 9 Tahun 2004, dan UU Nomor 3Tahun2006);

b. Jaksa(UU Nomor 16 Tahun 2004).

3) 60 (enam puluh) tahun bagi PNS yang menduduki jabatan Guru (UU Nomor 14 Tahun 2005)

\footnotetext{
${ }^{12} \mathrm{Ibid}$.
}

${ }^{13}$ Ibid. 
Adanya PP Nomor 65 Tahun 2008, maka bagi PNS yang menduduki jabatan struktural eselon I tertentu, BUP dapat diperpanjang sampai dengan 62 (enam puluh dua) tahun. Adapun perpanjangan sebagaimana dimaksud dilaksanakan dengan persyaratan sebagaimana yang telah di sebutkan di atas. Dan Perpanjangan BUP sampai dengan 62 (enam puluh dua) tahun ditetapkan dengan Keputusan Presiden atas usul Pimpinan Instansi/Lembaga setelah mendapat pertimbangan dari Tim Penilai Akhir Pengangkatan, Pemindahan, dan Pemberhentian dalam dan dari Jabatan Struktural Eselon I.

Dalam rangka mewujudkan kesejahteraan Pegawai Negeri Sipil (PNS), hal ini juga termasuk salah satu yang diatur pada Pasal 32 ayat (1)Undang-Undang Nomor 43 Tahun 1999 disebutkan bahwa untuk meningkatkan kegairahan bekerja, diselenggarakan usaha kesejahteraan Pegawai Negeri Sipil. Adapun usaha kesejahteraan sebagaimana dimaksud dalam ayat (1), selanjutnya sesuai Pasal 32 ayat (2) meliputi program pensiun dan tabungan hari tua, asuransi kesehatan, tabungan perumahan dan asuransi pendidikan bagi putra putri Pegawai Negeri Sipil.

Sesuai dengan amanat pasal 32 ayat (1), (2), dan (3) untuk menyelenggarakan program yang meningkatkan kesejahteraan PNS yang berupa pemberian pensiun pada khususnya, Pasal 32 ayat (4) menyebutkan bahwa pemerintah menanggung subsidi dan iuran, yang sebelumnya di ayat (3) mewajibkan PNS untuk membayar iuran setiap bulan dari penghasilannya. Kebijakan tentang pemberian pensiun yang diatur dalam Undang-Undang Nomor 43 Tahun 1999 merupakan kewenangan pemerintah, karena hal ini terkait dengan tanggung jawab Pemerintah dalam penyetaraan kesejahteraan pegawai secara nasional dan adanya jaminan bagi setiap Pegawai Negeri Sipil akan masa depannya yang akan diperolehnya terkait dengan tugas dan tanggung jawab yang telah dilaksanakannya. Untuk besaran subsidi dan iuran yang telah disebutkan dalam ayat (4) ditetapkan dengan Peraturan Pemerintah.

Ada berbagai macam sistem pensiun yang dikenal selama ini dan lazim diterapkan di beberapa negara, yaitu sistem pensiun manfaat pasti (defined benefit) dan sistem pensiun iuran pasti (defined contribution). Manfaat pasti adalah sistem pensiun dimana pemberi kerja memberikan sejumlah uang pensiun kepada pekerja/pegawai dengan jumlah tertentu. Uang tersebut dihitung berdasarkan formula perkalian antara penghasilan terakhir pegawai, masa kerja, usia, dan faktor tingkat bunga (actual rate). Formula manfaat atau nilai manfaat pensiun diatur dan ditentukan sebelumnya. Sistem pensiun ini merupakan sistem pensiun PNS yang saat ini diterapkan dengan dasar Undang-Undang Nomor 11 Tahun 1969 tentang Pensiun Pegawai dan Pensiun Janda/Duda Pegawai. ${ }^{14}$

Sedangkan iuran pasti adalah sistem pensiun dimana jumlah iuran tahunan atau bulanan yang berasal dari pegawai dan pemberi kerja. Namun pemberi kerja tidak menentukan besaran manfaat pensiun yang akan dibayarkan kepada pegawai. Manfaat pensiun sepenuhnya berasal dari jumlah iuran yang dibayar oleh pegawai, iuran pemerintah, dan akumulasi penghasilan/biaya-biaya yang berasal dari investasi terhadap iuran pensiun tersebut oleh penyelenggara pensiun. Sistem ini menyediakan akun individu kepada setiap pegawai. Apabila investasi yang dilakukan menghasilkan kerugian, maka rata-rata manfaat pensiun yang diterima pegawai akan berkurang. Akan tetapi sebaliknya, apabila investasi yang dilakukan menghasilkan keuntungan, maka rata-rata manfaat pensiun yang diterima pegawai akan bertambah. ${ }^{15}$

Pembiayaan pensiun sebagaimana diamanatkan dalam Undang-Undang Nomor 43

${ }^{14}$ Hadi, A. (2017). "Rancangan Sistem Jaminan Pensiun dan Hari Tua Pegawai Negeri Sipil (PNS)", Jurnal Civil Apparatus Policy, 003 (1), h.2.

15 Ibid. 
Tahun 1999 tentang Pokok-Pokok Kepegawaian di Pasal 32 dilakukan melalui sharing payment, yaitu dari iuran PNS (sebagai pekerja) dan iuran pemerintah (sebagai pemberi kerja). Karena dana pensiun belum terbentuk, maka pemerintah membayar langsung manfaat pensiun PNS (dengan sistem pay us you go) dengan menggunakan dana APBN.

Secara umum, terdapat dua sistem pendanaan program pensiun, yaitu sistem pendanaan langsung pay as you go system dan sistem pendanaan penuh atau fully funded system. Penjelasan kedua sistem tersebut menurut Rakhmawanto adalah sebagai berikut : ${ }^{16}$

a. Sistem Pendanaan Langsung (Pay as You Go System)

Istilah pendanaan langsung merujuk pada istilah pay as you go atau current disbursement. Metode ini adalah bahwa iuran pada program hanya bersumber dari Pemerintah, saat pembayaran iuran bersama dengan saat pembayaran pensiun, besarnya iuran sama dengan pembayaran pensiun, dan sarana pembayaran bersamaan dengan pembayaran gaji PNS, dapat melalui media pembayaran yang sama atau berbeda dengan pembayaran gaji. Keuntungan dari metode inin antara lain pengendalian pembayaran terutama penetapan besar pensiun ditangani Pemerintah, penganggar Pemerintah, berdasarkan prakiraan keadaan nyata (cash basic), adapun kerugiannya antara lain peningkatan pensiun dari tahun ke tahun, akibat penambahan penerimaan pensiun, sekalipun tidak terdapat kenaikan gaji atau pensiun, peningkatan pembayaran akan terjadi karena lama kehidupan penerima pensiun makin panjang, sejalan dengan peningkatan kesehatan masyarakat terutama bila usia pensiun tidak berubah dan lama pembayaran akan lebih panjang karena adanya pembayaran pensiun bagi tertanggung (istri/suami dan anak/atau anakanak).

b. Sistem Pendanaan Penuh (Fully Funded System)

Dalam metode ini iuran dapat bersumber dari Pemerintah bersama PNS, iuran dijadwalkan mendahului pembayaran manfaat pensiun dan tabungan hari tua, iuran Pemerintah terdiri dari iuran tetap (tahunan) berdasarkan pada penghasilan PNS dan atas nama PNS, dan iuran tambahan bila diperlukan untuk pedanaan, iuran PNS bila ada berdasar bagian tertentu dari penghasilan setiap bulannya, alokasi penganggaran iuran sebagai bagian dari penghasilan PNS dan untuk memungkinkan pengembangan dana, pengelolaan program dipisahkan dari pengelolaan Pemerintah. Keuntungan metode ini antara lain bahwa beban anggaran Pemerintah, beban Pemerintah untuk pembayaran iuran dapat diprakirakan bersamaan dengan pembayaran penghasilan PNS pada saat jumlah PNS tidak bertambah, maka iuran Pemerintah hanya akan meningkat karena adanya pengaruh penyesuaian inflasi atau tingkat kehidupan dan beban iuran tambahan dapat dialokasikan secara terprakirakan dan tetap dalam jangka waktu tertentu.

16 Rakhmawanto, A. (2014). "Program Pensiun Pegawai Negeri Sipil: Analisis Prespektif Perbaikan Sistem Pensiun PNS Dari Pay As You Go Ke Fully Funded”, Jurnal Kebijakan Dan Manajemen PNS, 8 (2), h. 9. 
Tabel $1^{17}$

Perbandingan Sistem Pendanaan Program Pensiun Pay as You Go dan Fully Funded

\begin{tabular}{|l|l|l|}
\hline & \multicolumn{1}{|c|}{ Pay as You Go } & \multicolumn{1}{|c|}{ Fully Funded } \\
\hline Sumber Dana & $\begin{array}{l}\text { Subsidi dari pemberi kerja } \\
\text { (Pemerintah/Pengusaha) }\end{array}$ & $\begin{array}{l}\text { Dikumpulkan dari iuran } \\
\text { bersama, peserta dan } \\
\text { pemberi kerja }\end{array}$ \\
\hline Dampak & Tidak terjadi akumulasi dana & $\begin{array}{l}\text { Terjadi akumulasi dana } \\
\text { sehingga menjadi } \\
\text { tabungan masa depan }\end{array}$ \\
\hline $\begin{array}{l}\text { Cadangan Keuangan } \\
\text { Nasional }\end{array}$ & $\begin{array}{l}\text { Tidak menciptakan cadangan } \\
\text { keuangan nasional }\end{array}$ & $\begin{array}{l}\text { Menciptakan cadangan } \\
\text { keuangan nasional }\end{array}$ \\
\hline Dampak Jangka Panjang & Memberatkan pemberi kerja & $\begin{array}{l}\text { Meningkatkan pera } \\
\text { kerja }\end{array}$ \\
\hline Produk Domestik Bruto & Tidak menaikkan PDB & Menaikkan PDB \\
\hline $\begin{array}{l}\text { Dampak terhadap } \\
\text { Lapangan Pekerjaan }\end{array}$ & $\begin{array}{l}\text { Tidak menciptakan lapangan } \\
\text { pekerjaan }\end{array}$ & $\begin{array}{l}\text { Menciptakan } \\
\text { pekerjaan }\end{array}$ \\
\hline $\begin{array}{l}\text { Dampak terhadap } \\
\text { Productive Capital }\end{array}$ & $\begin{array}{l}\text { Tidak menciptakan } \\
\text { productive }\end{array}$ & \multicolumn{2}{|c|}{ mangan } \\
\hline
\end{tabular}

\section{Pengaturan Pensiun Bagi Pegawai Negeri Sipil (PNS) Dalam Undang-Undang Nomor 5 Tahun 2014 Tentang Aparatur Sipil Negara}

Tanggal 15 Januari 2014 merupakan tonggak baru bagi pembaharuan manajemen pengelolaan Pegawai Negeri Sipil melalui Undang-Undang (UU) No. 5 tahun 2014 tentang Aparatur Sipil Negara. Namun demikian, dengan diberlakukan-nya UU ASN ini, peraturan-peraturan perundang-undangan yang merupakan peraturan pelaksanaan dari Undang-Undang Nomor 8 Tahun 1974 tentang Pokok-Pokok Kepegawaian, sebagaimana telah diubah dengan Undang-Undang Nomor 43 Tahun 1999 tentang Perubahan atas Undang-Undang Nomor 8 Tahun 1974 tentang Pokok-Pokok Kepegawaian dinyatakan masih tetap berlaku sepanjang tidak bertentangan dan belum diganti berdasarkan Undang Undang ini(Undang-Undang (UU) No. 5 tahun 2014 tentang Aparatur Sipil Negara, Pasal 139). ${ }^{18}$

Lahirnya UU ASN ini dilatarbelakangi atas suatu pemikiran bahwa pelaksanaan manajemen aparatur sipil negara selama ini belum mencerminkan perbandingan antara kompetensi dan kualifikasi yang diperlukan oleh jabatan dengan kompetensi dan kualifikasi yang dimiliki calon dalam rekrutmen, pengangkatan, penempatan, dan promosi pada jabatan sejalan dengan tata kelola pemerintahan yang baik (UndangUndang (UU) No. 5 tahun 2014 tentang Aparatur Sipil Negara. Beberapa perubahan mendasar terkait manajemen pengelolaan PNS dalam UU ASN antara lain pengertian tentang ASN maupun PNS maupun PPPK yaitu:

17 Suryanto. (2014). "Sistem Pensiun PNS: Mewujudkan Sistem Pendanaan Pensiun Fully Funded", Jurnal Kebijakan Dan Manajemen PNS, 8 (2), h. 87.

18 Haryanto. (2014). "Implementasi Undang-Undang ASN Dan Implikasinya Terhadap Manajemen Pengelolaan Jabatan Fungsiona”, Simpul Perencana, 22 (2), h. 62. 
1) Aparatur Sipil Negara yang selanjutnya disingkat ASN adalah profesi bagi pegawai negeri sipil dan pegawai pemerintah dengan perjanjian kerja yang bekerja pada instansi pemerintah.

2) Pegawai Aparatur Sipil Negara yang selanjutnya disebut Pegawai ASN adalah pegawai negeri sipil dan pegawai pemerintah dengan perjanjian kerja yang diangkat oleh pejabat pembina kepegawaian dan diserahi tugas dalam suatu jabatan pemerintahan atau diserahi tugas negara lainnya dan digaji berdasarkan peraturan perundang-undangan.

3) Pegawai Negeri Sipil yang selanjutnya disingkat PNS adalah warga negara Indonesia yang memenuhi syarat tertentu, diangkat sebagai Pegawai ASN secara tetap oleh pejabat pembina kepegawaian untuk menduduki jabatan pemerintahan.

4) Pegawai Pemerintah dengan Perjanjian Kerja yang selanjutnya disingkat PPPK adalah warga negara Indonesia yang memenuhi syarat tertentu, yang diangkat berdasarkan perjanjian kerja untuk jangka waktu tertentu dalam rangka melaksanakan tugas pemerintahan.

Hak PNS dan PPPK sebagai pegawai ASN sama, kecuali dalam hal pensiun dan jaminan hari tua, serta fasilitas. Jabatan ASN terdiri atas: Jabatan Administrasi (administrator, pengawas, dan pelaksana), Jabatan Fungsional; dan Jabatan Pimpinan Tinggi (utama, madya, pratama). Keberadaan Komisi Aparatur Sipil Negara (KASN) untuk monitoring dan evaluasi pelaksanaan kebijakan dan Manajemen ASN, yang merupakan lembaga nonstruktural yang mandiri dan bebas dari intervensi politik.

Pada Pasal 21 Undang-Undang Nomor 5 Tahun 2014 Tentang Aparatur Sipil Negara, disebutkan bahwa Pegawai Negeri Sipil berhak memperoleh hak-hak yang salah satunya merupakan hak jaminan pensiun dan jaminan hari tua. Berdasarkan Putusan MK, Nomor 15/PUU-XIV/2016, jaminan pensiun dan jaminan hari tua adalah bukan utang negara melainkan hak yang harus dijamin oleh negara. Jaminan pensiun dan jaminan hari tua merupakan hak-hak kepegawaian yang harus diberikan kepada pensiunan ASN/PNS yang telah memenuhi syarat, tanpa dibatasi oleh batas waktu (kadaluarsa) dalam pembayarannya. ${ }^{19}$

Kebijakan terkait dengan Sistem Pensiun PNS ditetapkan oleh Menteri sebagaimana dimaksud dalam Pasal 26 UU ASN. Sedangkan penyelenggaraan Manajemen ASN dalam bidang pertimbangan teknis dan persetujuan pensiun dilaksanakan oleh Badan Kepegawaian Negara (BKN). Hal tersebut disebutkan dalam Pasal 47 dan Pasal 55 bahwa BKN memiliki fungsi penyelenggaraan Manajemen ASN diantaranya meliputi jaminan pensiun. Manajemen Pegawai Negeri Sipil meliputi penetapan formasi, pengadaan pengangkatan, pemindahan, pemberhentian, penetapan pensiun, gaji dan tunjangan kesejahteraan, hak dan kewajiban hukum. ${ }^{20}$

Undang-Undang Nomor 5 Tahun 2014 ini juga mengatur tentang Pemberhentian PNS. Pasal 87 menyatakan bahwa PNS diberhentikan dengan hormat karena 1). Meninggal dunia; 2) atas permintaan sendiri; 3) mencapai batas usia pensiun; 4) perampingan organisasi atau kebijakan pemerintah yang mengakibatkan pensiun dini; atau 5) tidak cakap jasmani dan/atau rohani sehingga tidak dapat menjalankan tugas dan kewajibannya sebagai PNS. Batas usia Pensiun adalah batas usia Pegawai Negeri Sipil harus diberhentikan sebagai Pegawai Negeri Sipil. Lebih lanjut dijelaskan dalam Pasal 90 UU ASN:

19 Mahkamah Konstitusi, Putusan MK Nomor 15/PUU-XIV/2016 Tentang Jaminan Pensiun Dan Jaminan Hari Tua, Aparatur Sipil Negara Dan Pegawai Negeri Sipil.

20 Riawan, T. W. (2008). "Hukum Administrasi Negara", Yogyakarta: Universitas Atmajaya, h. 148. 
Batas usia pensiun sebagaimana dimaksud dalam Pasal 87 ayat (1) huruf c yaitu:

a) 58 (lima puluh delapan) tahun bagi Pejabat Administrasi;

b) 60 (enam puluh) tahun bagi Pejabat Pimpinan Tinggi;

c) sesuai dengan ketentuan peraturan perundang-undangan bagi Pejabat Fungsional.

Lebih lanjut dijelaskan dalam PP Nomor 21 Tahun 2014 Pasal 2 bahwa Batas Usia Pensiun yaitu: $:^{21}$

a) 58 tahun bagi Pejabat Fungsional Ahli Muda dan Ahli Pertama serta Pejabat Fungsional Ketrampilan;

b) 60 tahun bagi bagi Pegawai Negeri Sipil yang memangku:

1) Jabatan fungsional Ahli Utama dan Ahli Madya;

2) Jabatan Fungsional Apoteker;

3) Jabatan Fungsional Dokter yang ditugaskan secara penuh pada unit pelayanan kesehatan negeri;

4) Jabatan Fungsional Dokter Gigi yang ditugaskan secara penuh pada unit pelayanan kesehatan negeri;

5) Jabatan Fungsional Dokter Pendidik Klinis Muda dan Pertama;

6) Jabatan Fungsional Medik Veteriner;

7) Jabatan Fungsional Penilik;

8) Jabatan Fungsional Pengawas Sekolah;

9) Jabatan Fungsional Widyaiswara Madya dan Muda; atau

10) Jabatan Fungsional Lain yang ditentukan oleh Presiden;

c) 65 tahun bagi Pegawai Negeri Sipil yang memangku:

1) Jabatan Fungsional Peneliti Utama dan Peneliti Madya yang ditugaskan secara penuh di bidang penelitian;

2) Jabatan Fungsional Dokter Pendidik Klinis Utama dan Madya;

3) Jabatan Fungsional Widyaiswara Utama;

4) Jabatan Fungsional Pengawas Radiasi Utama;

5) Jabatan Fungsional Perekayasa Utama;

6) Jabatan Fungsional Pustakawan Utama;

7) Jabatan Fungsional Pranata Nuklir Utama; atau

8) Jabatan Fungsional lain yang ditentukan oleh Presiden.

Regulasi BUP yang dituangkan dalam UU No.5 Tahun 2014 merupakan kebijakan publik level negara. Proses penyusunan hingga ratifikasinya tidak hanya melibatkan lembaga executive saja, tetapi juga melibatkan DPR sebagai lembaga legislative yang mewakili seluruh rakyat Indonesia. Kebijakan level negara ini direncanakan mengikat semua WN di semua daerah dan di semua sektor diseluruh wilayah hukum Republik Indonesia. Oleh karena itu menuntut sifat yang general, mayor, konsepsual dan strategis di tingkat nasional. Dengan kata lain kebijakan ini kebijakan ini lebih banyak menuntut format regulasi dan definisi konsep dengan tingkatan abstraksi yang tinggi dan berfungsi strategis di tingkat nasional, daripada format teknis operasional yang spesifik. ${ }^{22}$

Dibandingkan dengan UU Nomor 8 Tahun 1974, norma BUP dalam UndangUndang Nomor 5 Tahun 2014 menggunakan batasan yang lebih ketat dan lebih operasional. Batasan yang lebih ketat dan operasional ini membuat ketentuan itu bisa

21 Republik Indonesia, Peraturan Pemerintah Nomor 21 Tahun 2014 Tentang Pemberhentian Pegawai Negeri Sipil Yang Mencapai Batas Usia Pensiun Bagi Pejabat Fungsional, LN Tahun 2014 Nomor 58.

22 Pambudi, A., Kumoro, J. (2014). “Analisis Peraturan Batas Usia Pensiun PNS Dalam UU No. 5 Tahun 2014 Tentang Aparatur Sipil Negara, Fakultas Ilmu Sosial Universitas Negeri Yogyakarta, h. 10. 
langsung dilaksanakan tanpa harus menunggu terbitnya peraturan pelaksanaanya ketika mereka harusnya membuat keputusan yang "berbeda" dengan definisi ketat aturan UU ini. Disatu sisi ketentuan hukum yang ketat ini lebih baik karena menciptakan kepastian hukum yang seragam dan mudah dilaksanakan.

Regulasi Batas Usia Pensiun bagi PNS dalam UU Nomor 5 Tahun 2014 ini tergolong sedikit. Substansinya hanya termuat dalam 3 Pasal yaitu Pasal 87, 90, dan 91. Bila dibandingkan dengan UU yang digantikannya, yaitu UU No. 8 Tahun 1974 tentang Pokok-Pokok Kepegawaian dan perubahannya, porsi tersebut sudah jauh lebih besar. Selanjutnya, dipadu dengan tingkat abstraksi definisi konsep yang digunakannya maka perpaduan ini berkonsekuensi memunculkan potensi masalah di tingkat implementasi. Singkatnya, format regulasi Batas Usia Pensiun yang terkandung dalam UU No. 8 Tahun 1974 itu memiliki tingkat abstraksi yang tinggi. Pola pengaturan batas usia pensiun seperti ini memiliki keunggulan inherent di dalamnya, yaitu tidak mudah usang atau ketinggalan jaman karena lebih mampu menyesuaikan diri dengan dinamika, perubahan bentuk dan struktur permasalahan yang disasar melalui fleksibilitas peraturan pelaksanaannya. $^{23}$

Pasal 91 UU ASN menjelaskan lebih lanjut tentang Jaminan Pensiun dan Jaminan Hari Tua yaitu PNS akan diberikan jaminan pensiun apabila meminggal dunia, atas permintaan sendiri dengan usia dan masa kerja tertentu, mencapai batas usia pensiun, perampingan organisasi atau kebijakan pemerintah yang mengakibatkan pensiun dini, ataupun apabila seorang PNS tidak cakap jasmani dan/atau rohani sehingga tidak dapat menjalankan tugas dan kewajibannya. Jaminan Pensiun mencakup jaminan pensiun dan jaminan hari tua yang diberikan dalam program jaminan sosial nasional. Sumber pembiayaan jaminan pensiun dan jaminan hari tua PNS berasal dari pemerintah selaku pemberi kerja dan iuran PNS yang bersangkutan.

Jaminan pensiun dan jaminan hari tua PNS mencakup jaminan pensiun dan jaminan hari tua yang diberikan dalam program jaminan sosial nasional. Kebijakan baru sistem pensiun PNS akan diubah dengan sistem fully funded. Skema fully funded menggunakan pola iuran pasti, dimana terdapat iuran yang ditetapkan diawal yang harus dibayarkan bersama antara PNS dengan pemerintah selaku pemberi kerja. ${ }^{24}$

Dana pensiun akan dikelola secara profesional yang dapat memberikan manfaat pasti bagi pensiunan PNS. Sebagaimana diamanatkan dalam UU ASN Pasal 91 Ayat (5) bahwa sumber pembiayaan jaminan pensiun dan jaminan hari tua PNS berasal dari pemerintah selaku pemberi kerja dan iuran PNS yang bersangkutan. Pemerintah sebagai pemberi kerja diwajibkan memberikan iuran yang lebih besar dibandingkan dengan iuran pegawai sebagai pekerja. Dana tersebut (iuran pemerintah dan iuran pegawai) akan dikumpulkan dalam bentuk dana pensiun yang dapat dikembangkan atau diinvestasikan. ${ }^{25}$

Hasil dari pengembangan dana pensiun nantinya dapat digunakan untuk pembiayaan belanja pensiun secara jangka panjang. Sehingga belanja pensiun tidak menjadi beban APBN setiap tahunnya sebagaimana selama ini berjalan. Disamping itu akan bisa didapatkan alternatif sumber pembiayaan pensiun melalui dana pajak penghasilan terhadap PNS yang selama ini ditanggung oleh pemerintah. Pajak penghasilan yang dibayar oleh PNS, akan digunakan oleh pemerintah untuk membayar iuran pemerintah dalam dana pensiun dan dana tabungan pensiun. Model ini akan memprediksi bahwa dalam waktu 30 tahun ke depan, pemerintah dapat terbebas dari

23 Ibid, h. 11.

24 Hadi, A. Op. Cit. h. 3.

25 Ibid. 
beban belanja pensiun yang ditanggung oleh APBN. ${ }^{26}$

\section{P E N U T U P}

Perbandingan pengaturan pensiun bagi Pegawai Negeri Sipil (PNS) dalam Undang-Undang Nomor 43 Tahun 1999 Tentang Pokok-Pokok Kepegawaian dan pengaturan pensiun bagi Aparatur Sipil Negara (ASN) dalam Undang-Undang Nomor 5 Tahun 2014 tentang Aparatur Sipil Negara yaitu secara spesifik terdapat perubahan terhadap ketentuan Batas Usia Pensiun (BUP) Pegawai Negeri Sipil (PNS). Pada UndangUndang Nomor 43 Tahun 1999 Tentang Pokok-Pokok Kepegawaian yang juga diatur dalam Peraturan Pemerintah (PP) Nomor 32 Tahun 1979 tentang Pemberhentian PNS, yaitu 56 (lima puluh enam) tahun, 65 tahun untuk PNS yang memangku jabatan peneliti madya dan peneliti utama , 60 tahun untuk PNS yang memangku golongan struktural eselon I dan II serta jabatan dokter. Dana untuk membayar manfaat pensiun melalui Anggaran Pendapatan dan Belanja Negara (APBN) menggunakan sistem pay as you go menjadi problem karena membebani keuangan negara dan terus mengalami peningkatan. Pada UU Nomor 5 Tahun 2014 ketentuan mengenai batas usia pensiun berubah menjadi 58 (lima puluh delapan) tahun bagi Pejabat Administrasi dan 60 (enam puluh) tahun bagi Pejabat Pimpinan Tinggi. Dibandingkan dengan UU Nomor 8 Tahun 1974, norma BUP dalam Undang-Undang Nomor 5 Tahun 2014 menggunakan batasan yang lebih ketat dan lebih operasional. Batasan yang lebih ketat dan operasional ini membuat ketentuan itu bisa langsung dilaksanakan tanpa harus menunggu terbitnya peraturan pelaksanaanya ketika mereka harusnya membuat keputusan yang "berbeda" dengan definisi ketat aturan UU ini. Disatu sisi ketentuan hukum yang ketat ini lebih baik karena menciptakan kepastian hukum yang seragam dan mudah dilaksanakan. Kebijakan baru sistem pensiun PNS akan diubah dengan sistem fully funded. Skema fully funded menggunakan pola iuran pasti, dimana terdapat iuran yang ditetapkan diawal yang harus dibayarkan bersama antara PNS dengan pemerintah selaku pemberi kerja.

\section{DAFTAR PUSTAKA}

\section{Buku}

[1] Djatmika, S. dan Marsono. (1995) Hukum Kepegawaian Di Indonesia, Jakarta:Djambatan.

[2] Ibrahim, J. (2005). Teori Dan Metodologi Penelitian Hukum Normatif, Surabaya: Bayu Media Publishing.

\section{Jurnal}

[3] Haryanto. (2014). "Implementasi Undang-Undang ASN Dan Implikasinya Terhadap Manajemen Pengelolaan Jabatan Fungsiona”, Simpul Perencana, 22 (2).

[4] Hadi, A. (2017). "Rancangan Sistem Jaminan Pensiun dan Hari Tua Pegawai Negeri Sipil (PNS)", Jurnal Civil Apparatus Policy, 003 (1)

[5] Rakhmawanto, A. (2014). "Program Pensiun Pegawai Negeri Sipil: Analisis Prespektif Perbaikan Sistem Pensiun PNS Dari Pay As You Go Ke Fully Funded", Jurnal Kebijakan Dan Manajemen PNS, 8 (2).

[6] Suryanto. (2014). "Sistem Pensiun PNS: Mewujudkan Sistem Pendanaan Pensiun

\footnotetext{
26 Ibid, h. 4.
} 
Fully Funded”, Jurnal Kebijakan Dan Manajemen PNS, 8 (2).

\section{Skripsi, Tesis, Disertasi dan Lain-Lain}

[7] Pambudi, A., Kumoro, J. (2014). “Analisis Peraturan Batas Usia Pensiun PNS Dalam UU No. 5 Tahun 2014 Tentang Aparatur Sipil Negara, Fakultas Ilmu Sosial Universitas Negeri Yogyakarta.

[8] Riawan, T. W. (2008). "Hukum Administrasi Negara", Yogyakarta: Universitas Atmajaya

\section{Online/World Wide Web}

[9] Adhi, A. E, "Modul Pengertian Dan Ruang Lingkup Pemberhentian Dan Pensiun Pegawai", Http://Repository.Ut.Ac.Id/3945/1/ADPG4447-M1.Pdf , (Diakses pada 22 November 2019).

[10] Badan Perencanaan Pembangunan Nasional, "Menuju Perencanaan Profesional, SIMPUL

Perencanaan",

Http://Pusbindiklatren.Bappenas.Go.Id/File/Bukuterbit/Simpul-22.Pdf， (Diakses pada 22 November 2019).

[11] Dewan Perwakilan Rakyat, "Ringkasan Eksekutif Telaahan Kebijakan Sistem Pensiun PNS“, Http://Ppid.Lan.Go.Id/Wp-Content/Uploads/2014/10/TelaahanKebijakan-Sistem-Pensiun-PNS.Pdf, (Diakses pada 22 November 2019)

[12] Deasy Ayu, "Dana Pensiun Pegawai Negeri Sipil”, Https:/Www.Academia.Edu/30712453/DANA_PENSIUN_ PEGAWAI_NEGERI_SIPIL, (Diakses pada 22 November 2019)

[13] http://Taspen.Co.Id, (Diakses pada 22 November 2019).

[14] "Pensiun", Http://Bkpsdm.Kuningankab.Go.Id/Pelayanan/Pensiun. (Diakses pada 23 November 2019).

[15] "Pedoman

Pemberhentian PNS", Http://Www.Bkn.Go.Id/In/Peraturan/Pedoman/Pedoman-Berhenti-Pns.html, (Diakses pada 23 November 2019). 